\title{
Europejski Zielony Ład w kontekście zrównoważonego rozwoju miast jako remedium na kryzys ekologiczny i pandemię
}

\section{The European Green Deal in the context of sustainable urban development as a remedy for the ecological crisis and the pandemic}

\section{Streszczenie}

Doświadczenie pandemii COVID-19 oraz narastający kryzys klimatyczny wymusiły podjęcie skuteczniejszych działań naprawczych. Jednym z nich jest strategia Europejskiego Zielonego Ładu definiująca podstawowe obszary problemowe i zakres niezbędnych zmian. Artykuł przedstawia tendencje w działaniach proekologicznych i postpandemicznych, mające wpływ na współczesny paradygmat urbanizacji w skali miasta "sąsiedzkiego" przy jednoczesnej trosce o środowisko.

Słowa kluczowe: Europejski Zielony Ład, rozwój zrównoważony, miasto postpandemiczne, urbanistyka „post-2020”, kryzys klimatyczny

\begin{abstract}
The experience of the COVID-19 pandemic and the growing climate crisis have forced us to take more effective corrective actions. One of these is the European Green Deal strategy, which defines areas of concern and the scope of changes that are deemed necessary. This article aims to review the trends in pro-ecological and post-pandemic activities that affect the contemporary paradigm of urbanisation on the scale of a "neighbourhood" city with concern for the environment.
\end{abstract}

Keywords: European Green Deal, sustainable development, post-pandemic city, "post-2020" urban planning, climate crisis 


\section{WSTĘP}

Kryzys ekologiczny jest globalnym zjawiskiem o charakterze poziomym, obejmującym wszystkie kontynenty, ale również i pionowym, obejmującym zagadnienia biologiczne, społeczne, gospodarcze i polityczne. Artykuł dotyczy państw Unii Europejskiej i spraw związanych z Europejskim Zielonym Ładem w zakresie ograniczeń zanieczyszczeń przemysłowych, emisji dwutlenku węgla, powstania nowych źródeł energii oraz porusza problematykę pogorszenia się psychofizycznej sytuacji człowieka z uwagi na pandemie COVID-19.

Brak troski o ekologię ze strony człowieka, klimatyczne zmiany i wzrost temperatury na Ziemi spowodowany emisją gazów cieplarnianych skutkują ekstremalnymi zjawiskami pogodowymi, topnieniem lodowców, powodziami czy falami upałów. Przeciętna temperatura na naszej planecie jest wyższa o ponad $1^{\circ} \mathrm{C}$ w porównaniu do poziomów sprzed epoki przemysłowej ${ }^{1}$. Jako istotny pierwszy element walki ze zmianami ekosystemu w grudniu 2019 roku Komisja Europejska przedstawiła strategię służącą neutralności klimatycznej zaplanowanej na rok 2050. Jest to Europejski Zielony Ład, w którym najważniejszym elementem jest zerowy poziom emisji zanieczyszczeń na rzecz nietoksycznego środowiska. Sposobem na neutralność klimatyczną jest środowisko, w którym nie będą emitowane nowe zanieczyszczenia, jak również wprowadzone zostaną działania mające na celu redukcję i usunięcie istniejących już zanieczyszczeń. Unia Europejska postanowiła lepiej monitorować zanieczyszczenie powietrza, wody, gleby czy produktów konsumpcyjnych oraz informować o tych zanieczyszczeniach, zapobiegać im i usuwać ich skutki. W maju 2021 roku Komisja Europejska przyjęła plan działania na rzecz eliminacji zanieczyszczeń wody, powietrza i gleby. Przedstawiono zintegrowaną wizję świata do 2050 roku, w którym zanieczyszczenia środowiska zostają zredukowane do poziomów, które nie są już szkodliwe dla zdrowia ludzkiego i naturalnych ekosystemów. Drugim ważnym elementem po neutralności klimatycznej jest wzrost gospodarczy przy zahamowaniu zużycia surowców naturalnych. Do 2030 roku wszystkie opakowania używane na terenie Unii Europejskiej mają mieć możliwość ponownego przetworzenia, aby uzyskać gospodarkę o obiegu zamkniętym (Grendys, 2021). Plan łączy wszystkie odpowiednie polityki Unii Europejskiej w tym zakresie oraz przewiduje przegląd unijnego prawodawstwa pod kątem lepszego wdrażania (GOV, Europejski...). Trzecią grupą istotnych zagadnień jest problematyka energetyczna - rozwój systemów ekologicznych nieingerujących w ekosystem.

Najtrudniejszym do rozwiązania problemem dla naszej planety i jej środowiska jest szybko rosnąca liczba ludności na świecie. Według prognoz ONZ do końca wieku populacja na świecie osiągnie poziom 10,9 miliarda (Nosarzewska, 2020). Wzrost populacji bardzo silnie wpływa na wszystkie aspekty polityczne, gospodarcze i globalny ekosystem. Zmiany klimatyczne powodowane między innymi zanieczyszczeniami technologicznymi, przemysłowymi

Dane podane według Instytutu Meteorologii i Gospodarki Wodnej Państwowego Instytutu Badawczego (IMGW, 2020). 
i znaczącym wzrostem gazów cieplarnianych stają się coraz trudniejsze i bardziej dotkliwe dla życia miejskiego. Skutkować to może mniejszym dostępem do żywności oraz wody pitnej.

Pandemia przyspieszyła sytuację, w której zarówno obywatele, jak i politycy zaczęli domagać się zrównoważonej transformacji miast i większego kontrolowania wpływu deweloperów i grup przemysłowych na rozwój cywilizacyjny. Koniczne jest przywrócenie szacunku do ekosystemu globalnego i mikrolokalnego we współuczestnictwie w różnorodnym kulturowo społeczeństwie, otwartym na pokojowy rozwój. Architekci i projektanci mogą mieć na to ogromny wpływ, ponieważ projektowanie jest potężnym narzędziem do wprowadzania zmian w przestrzeni sąsiedzkiej, które są niezbędne do zatrzymania degradacji interspołecznej oraz degradacji ekosystemu. „Zielony ład” nie jest już tylko abstrakcyjnym sloganem, ale podstawowym elementem przyszłej rzeczywistości. Cywilizacja postindustrialna nie może się opierać tylko na paradygmacie cywilizacji technologicznej. Pomimo zaawansowanej technologii, rozwoju komunikacji międzyludzkiej poprzez media społecznościowe, globalna pandemia sprawiła, że jakość życia - w tym relacje społeczne - uległa degradacji. Konieczne jest przywrócenie tradycyjnego poczucia więzi sąsiedzkiej i identyfikacji lokalnej poprzez partycypacje nie tylko pasywną, lecz i aktywną w lokalnym projektowaniu przestrzeni społecznych. Działania takie winny opierać się na neuronauce oraz psychologii i socjologii.

\section{ZRÓWNOWAŻONY ROZWÓJ MIAST}

Miasto zrównoważone to miasto przyszłości. Do stworzenia miast zrównoważonych, w których jakość życia będzie zgodna z psychicznymi i fizycznymi potrzebami człowieka w możliwie naturalnym środowisku, należy zredefiniować koncepcję rozwoju. Innowacja nie powinna oznacza tylko „nowości”. Nowy, lepszy świat jest pojęciem dalece abstrakcyjnym i definiowanym w różny sposób w zależności od grupy społecznej, której dotyczy. Działania powinny być inkluzyjne, dzięki temu będziemy w stanie stworzyć najlepsze warunki bytowe dla wszystkich mieszkańców. Pandemia spowodowała eskalację wykorzystania technologii cyfrowej, co skutkuje też zmianą sposobu użytkowania mieszkań, budynków i miast. W projektowaniu zrównoważonego miasta i reorganizacji miast współczesnych należy uwzględnić wyniki badań proekologicznych i antypandemicznych.

Abyśmy mogli mówić o ekologicznym rozwoju naszej planety, należy zmienić kulturę oraz sposób myślenia. Do roku 2050 musimy obniżyć emisję gazów cieplarnianych o 50\%. Powinniśmy zastanowić się nad główną przyczyną podwyższonych wskaźników $\mathrm{CO} 2$ i skuteczną ich redukcją. Obecnie stosujemy rozwiązania, które w większości retuszują źródłowe problemy, kiedy powinny je rozwiązywać.

Wdrażanie systemów wodorowych w transporcie oraz energetyce przyczyni się do dekarbonizacji miast. Wodór uznawany jest za jeden z filarów wdrażania Europejskiego Zielonego Ładu. Polska zajmuje trzecie miejsce, zaraz po Niemczech i Holandii, pod względem całkowitej 
zdolności produkcji wodoru w Unii Europejskiej (Skłodowska, 2020). Jednym z 11 miast, które zaczynają wdrażać taki system, jest Gdynia. Została ona beneficjentem programu FCH Regions EU, wspierającego wdrażanie wodoru w transporcie i energetyce w krajach Unii Europejskiej (Sozosfera, 2019). Głównymi założeniami będzie wykorzystanie autobusów, pociągów i małych promów zasilanych wodorowymi ogniwami paliwowymi w komunikacji miejskiej. Województwo śląskie ma szansę stać się wodorowym liderem w Polsce. Dostało ono dofinansowanie na zakup 20 autobusów zasilanych wodorem (Tabaka, 2021). Czas ładowania takiego autobusu zajmuje poniżej 10 minut, a jego zasięg przekracza 500 km (Skłodowska, 2020). Zasilanie transportu wodorem jest wydajniejsze od transportu elektrycznego.

Polityka klimatyczna Unii Europejskiej wymusza transformacje energetyki. Energia jądrowa jest stabilnym, bezpiecznym i czystym źródłem energii, które umożliwi dekarbonizację. Możliwość zmagazynowania paliwa jądrowego na długi czas może poprawić niezależność energetyczną danego kraju. Energia jądrowa nie emituje $\mathrm{CO}^{2}$, co pozwala na osiągnięcie celów klimatycznych Unii Europejskiej. Jest ona jednym z najtańszych źródeł wytwarzania energii. Elektrownie jądrowe występują w wielu państwach Unii Europejskiej. Spółka joint venture Orlen Synthos Green Energy została powołana w celu komercjalizacji w Polsce technologii mikro i małych reaktorów jądrowych. Pierwszy mały reaktor jądrowy powstanie w Polsce do 2030 roku, wówczas koszty produkcji energii elektrycznej będą o około 30\% niższe niż w przypadku energii gazowej (PKN Orlen, 2021).

\section{URBANISTYKA}

Współcześnie projektując rozwój miasta, powinniśmy zastanowić się, jak zwiększyć jakość środowiska mieszkaniowego w jego wszystkich aspektach biologicznych, kulturowych, społecznych oraz funkcjonalnych i zminimalizować zużycie energii we wszystkich fazach istnienia budynków, mieszkalnych, biurowych, usługowych. Współcześnie miasta rozrastają się bardzo szybko, a zapotrzebowanie na nowe mieszkania jest bezgraniczne. Z dnia na dzień zielone przestrzenie w około miast zamieniają się na betonowe osiedla zabudowy mieszkaniowej. Brak w nich zieleni, podstawowych usług, przedszkoli, szkół czy miejsc pracy. Z powodu bardzo dużej ekspansji na tereny zielone niszczymy ekosystem. Jednym z problemów związanych z mieszkaniem za miastem (miasta-sypialnie), kiedy pracuje się w mieście, jest indywidualny transport - samochody. Codzienne dojazdy samochodem zanieczyszczają środowisko, jak również przyczyniają się do zmniejszenia naszego wolnego czasu, który moglibyśmy poświęcić rodzinie. Skutkiem rozproszonego budownictwa mieszkaniowego są korki, które są źródłem codziennego stresu. Zrównoważona transformacja wymaga ograniczenia indywidualnego transportu samochodowego oraz zmiany źródła zasilania w pojazdach komunalnych. Powinniśmy zmienić nasze miasta na takie, w których wszystko, czego potrzebujemy, znajduje się w odległości spaceru lub przejazdu rowerem - miasto „sąsiedzkie”. 
Epidemia wymusiła zmianę naszych nawyków. W czasie lockdownów większość czasu spędzaliśmy w domu, przemieszczanie było ograniczone, dlatego bogatsi o doświadczenie, które może się powtórzyć, widzimy potrzebę posiadania wszystkich niezbędnych funkcji życiowych blisko naszego miejsca zamieszkania. W mieście sąsiedzkim dostęp do szpitali, aptek, szkół, kultury jest dużo łatwiejszy, znajdują się one zawsze niedaleko od miejsca zamieszkania. Pandemia zmieniła także sposób korzystania z przestrzeni publicznej. Zamiast podróżowania środkami transportu publicznego - spacerujemy, jeździmy rowerem. Ponadto warto tutaj wspomnieć o spotkaniach w parku - na przestrzeni otwartej zamiast kawiarni czy centrów handlowych. Atrakcyjne parki i przestrzenie publiczne, ścieżki rowerowe i chodniki są dla miasta ważniejsze niż kiedykolwiek wcześniej. Podczas pandemii COVID-19 małe place miejskie, na których znajdują się lokalne sklepiki, są dużo lepszym rozwiązaniem niż duże centra handlowe. Zapewniają one lokalnym mieszkańcom dostęp do podstawowych artykułów spożywczych oraz ograniczają ryzyko infekcji. Zcentralizowanie podstawowych usług miejskich i ośrodków administracji zabiło lokalne place i rynki z obiektami o takim przeznaczeniu funkcjonujące od lat. Pandemia uzmysłowiła nam, iż model miasta „piętnastominutowego” jest elastyczną koncepcją, którą każde miasto powinno wdrożyć. „Miasto kwadrans” to koncepcja współtworzona przez francusko-kolumbijskiego naukowca Carlosa Moreno (Paris, 2021).

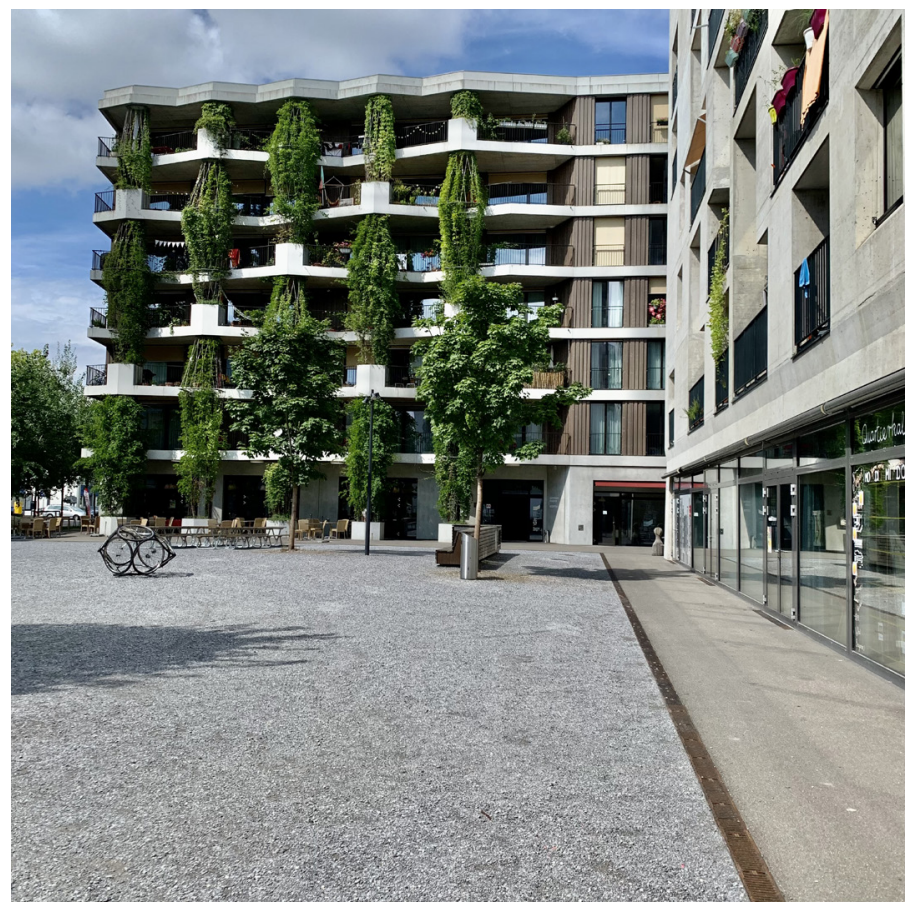


Taki model zakłada redukcję liczby zbędnych transferów oraz zapewnia bliskość sześciu podstawowych funkcji społecznych: mieszkanie, pracę, opiekę zdrowotną, sklepy, szkoły oraz rekreację. Zapewnia wzmocnienia poczucia wspólnoty. Ważnym elementem takiej koncepcji jest, aby w każdej dzielnicy były dostępne różne typy mieszkań, zapewniające każdemu możliwość zamieszkania, oraz dostęp do terenów zielonych. Decentralizacja życia i usług miejskich poprawi zrównoważony rozwój miast.

Przestrzenie publiczne, parki naturalne, ścieżki rowerowe, chodniki dla pieszych są kluczowymi elementami dla naszego zdrowia oraz dobrego samopoczucia. Przyczyniają się do budowania marki miasta, jak również do osiągnięcia bioróżnorodności, zapobiegania powodziom i falom upałów na terenach miejskich.

\section{ARCHITEKTURA BUDYNKÓW}

Zmiany społeczne a także pandemia spowodowały, że rolę budynków w miastach tworzy się na nowo. Funkcje budynków są dopasowywane do zmiennych społecznych, socjologicznych i wyzwań technologicznych, a ostatnio nawet do sytuacji epidemiologicznej. Poprzez postępujący rozwój technologii cyfrowej, wprowadzającej nas w wirtualny świat, ludzie coraz bardziej zagubieni są w przestrzeni realnej i nie potrafią określić swoich prawidłowych potrzeb. Aby mówić o zrównoważonym rozwoju miast, musimy zdefiniować współczesne paradygmaty budownictwa miejskiego. Nasze potrzeby zmieniają się szybko, co za tym idzie - budynki również muszą przechodzić szybkie adaptacje. Pandemia wytworzyła w nas większą potrzebę elastyczności. Budynki, żeby utrzymać swoją wartość użytkową, powinny być przystosowane do zmian. W ciągu ostatnich dwóch lat musieliśmy przetransformować nasze domy, miejsca pracy, szpitale, miejsca publiczne czy sklepy. Obecnie mamy potrzebę korzystania z domu jako miejsca pracy. Powinniśmy projektować elastyczne i dynamiczne przestrzenie, w których można przewidzieć zmianę użytkowania oraz unikanie konieczności wyburzania, przebudowy lub znacznej renowacji w celu zapobiegnięcia ich dezaktualizacji. Projektowanie przestrzeni mixed-use przyczyni się do rozwiązania problemów martwych przestrzeni miejskich oraz uatrakcyjnienia życia miejskiego. Doświadczyliśmy ograniczenia liczby osób w budynkach podczas różnych zbiorowych wydarzeń. Powinniśmy projektować więcej otwartych przestrzeni, np.: otwarte amfiteatry, place miejskie, aby w przyszłości łatwiej było organizować różnego rodzaju wydarzenia kulturalne - ze względu na pojawienie się wirusa COVID-19 odwołano spotkania czy koncerty w zamkniętych pomieszczeniach. Również budynki należy projektować tak, aby partery tworzyły interakcję pomiędzy wnętrzem budynku a zewnętrzną przestrzenią publiczną. Takie rozwiązania będą poszerzać relacje między wnętrzem obiektu a zewnętrzem, co spowoduje ponowne uatrakcyjnienie życia społecznego. Myśląc w ten sposób, sprawimy, że budynki nie przeszkodzą nam 
w spotkaniach, nauce, pracy, wizytach w urzędach, tak jak stało się to teraz podczas pandemii COVID-19, ale będą wspierać nowe możliwości.

Wykorzystanie dostępnych najnowszych technologii, „inteligentnych”, które pomogą zoptymalizować użycie energii w naszych domach, jest kluczowym elementem do zmniejszenia zapotrzebowania na energię elektryczną z nieodnawialnych źródeł. „Integracja technologii informacyjno-komunikacyjnych w systemie energetycznym może być kluczem do osiągnięcia dekarbonizacji zasobów budowlanych i przyspieszenia transformacji systemu energetycznego" (Janhunen i in., 2020). Już dzisiaj jesteśmy w stanie wykorzystać energię słoneczną czy wiatrową tylko w ilości, jakiej potrzebujemy, a nadwyżki przekazać do innych budynków.

Efektywność energetyczna, brak emisji szkodliwych dla środowiska substancji oraz dbałość o interakcje społeczne to nowe paradygmaty podczas projektowania, obejmujące nie tylko fizyczną samowystarczalność budynku i jego ekosprawność, ale również zagadnienie psychologii społecznej i socjologii. Wiele pozytywnych działań jest już realizowanych w Europie.

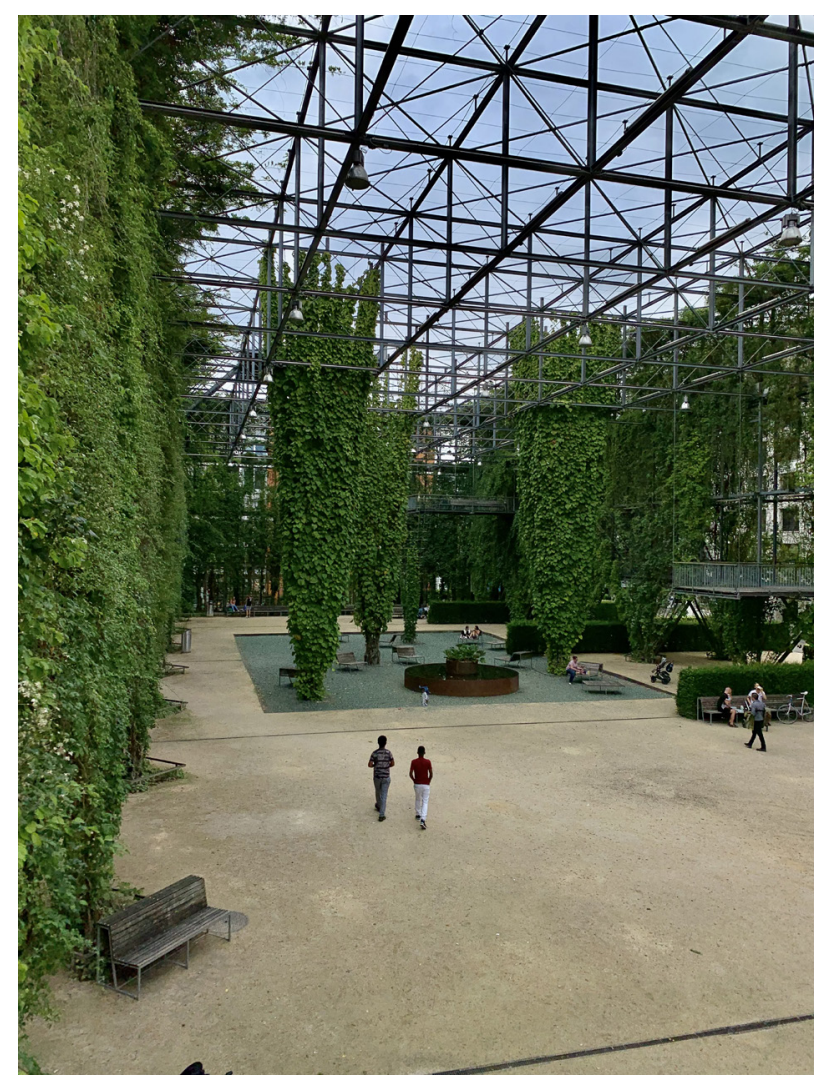

II. 2. Wprowadzenie zieleni do przestrzeni publicznej na przykładzie Haus E w Zurichu. Fot. autorka 


\section{PODSUMOWANIE}

Zielony Ład jest umownym określeniem dla wszystkich zjawisk, które są wymagane, aby zrównoważony rozwój miast stał się faktem, a nie tylko teorią. Kryzys ekologiczny sprawił, że dominujący w postindustrialnym świecie mit rozwoju technologii i techniki musi zostać rozszerzony o czynnik biologiczny i ludzki, za którym kryją się tradycje społeczne, akceptacja wielokulturowości, interakcje, dostępność do naturalnego środowiska i poszanowanie wartości ekosystemu. Globalizacja, technika i technologia winny służyć człowiekowi jako istocie ludzkiej nieodłącznie związanej z naturą, nawet w środowisku miejskim.

\section{BIBLIOGRAFIA}

Ellard, C. (2021). Przestrzenie serca. Psychogeografia życia codziennego. Wydawnictwo GSA. GOV. (b.d.). Europejski Zielony Ład. Pobrane z: https://www.gov.pl/web/wprpo2020/europejski-zielony-lad (dostęp: 10.12.2021).

GOV. (b.d.). Program polskiej energetyki jqdrowej. Pobrane z: https://www.gov.pl/web/polski-atom/program-polskiej-energetyki-jadrowej (dostęp: 05.09.2021).

Grendys, A. (2021). Sposoby na neutralność klimatycznq, czyli o co chodzi w Zielonym Ładzie. Pobrane z: https://przemyslprzyszlosci.gov.pl/sposoby-na-neutralnosc-klimatyczna-czyli-o-co-chodzi-w-zielonym-ladzie/?gclid=CjwKCAiAksyNBhAPEiwAIDBeLJJ1fxZB5olB65AX Ddmw8EebfONKIYrhU9kj_EtWsIfW3I5FvTZtvhoCeAMQAvD_BwE (dostęp: 10.12.2021). Janhunen, E., Leskinen, N., Junnila, S. (2020). The Economic viability of a progressive Smart Building System with Power Storage. MDPI Sustainability, 12(15), 5998.

Joseph, P., Tretsiakova-McNally, S. (2010). Sustainable Non-Metalic Building Materials. MDPI Sustainability, 2(2), 400-427.

Nosarzewska, E. (2020). Wzrost populacji świata i jego konsekwencje. Pobrane z: https://ptsp. pl/wzrost-populacji-swiata-i-jego-konsekwencje-megatrendy-2050/(dostęp: 05.09.2021).

PKN Orlen. (2021). Orlen rozwija technologię małego atomu. Pobrane z: https://www.orlen. $\mathrm{pl} / \mathrm{pl} / \mathrm{o}-\mathrm{firmie} / \mathrm{media} /$ komunikaty-prasowe/2021/orlen-rozwija-technologie-malego-atomu-SMR (dostęp: 11.12.2021).

Paris. (2021). Paris ville du quart d'heure, ou le pari de la proximite. Pobrane z: https://www. paris.fr/dossiers/paris-ville-du-quart-d-heure-ou-le-pari-de-la-proximite-37 (dostęp: 03.09.2021).

Sozosfera. (2019). Wdrażanie wodoru w transporcie i energetyce. Pobrane z: https://sozosfera. pl/zielona-energia/wdrazanie-wodoru-w-transporcie-i-energetyce/ (dostęp: 09.11.2021).

Tabaka, M. (2021). Polska może być wodorowq potęgq. Bruksela musi tylko zaczqć traktować szary wodór jak zielony. Pobrane z: https://spidersweb.pl/bizblog/wodor-europejskie-forum-przyszlosci/ (dostęp: 11.12.2021). 
IMGW. (2020). WMO: Prognoza klimatu na lata 2020-2024. Pobrane z: https://www.imgw. pl/wydarzenia/wmo-prognozy-klimatu-na-lata-2020-2024 (dostęp: 09.12.2021).

World Green Building Council. (b.d.). About Green Building. Pobrane z: https://www.worldgbc. org/how-can-we-make-our-buildings-green (dostęp: 05.09.2021).

Skłodowska, M. (2020). Kto zarobi na polskim wodorze? Pobrane z: https://wysokienapiecie. pl/32899-kto-zarobi-na-polskim-wodorze/ (dostęp: 11.12.2021). 